Jurnal Sikola: Jurnal Kajian Pendidikan dan Pembelajaran

VOL. 2 NO. 2 DESEMBER 2020

http://sikola.ppj.unp.ac.id

Email: sikola@ppj.unp.ac.id

ISSN: 2686-3413 (Print) 2715-1735 (Online)

DOI: https://doi.org/10.24036/sikola.v2i2.87

\title{
Pelaksanaan Penilaian Autentik dalam Pembelajaran Sosiologi Kelas X di SMA Negeri 1 Lubuk Basung
}

\author{
Afrizal Muhardi ${ }^{1}$, Ike Sylvia ${ }^{2}$ \\ ${ }_{1,2}$ Universitas Negeri Padang \\ Email: muhardiafrizal@gmail.com, ikesylvia@fis.unp.ac.id
}

\begin{abstract}
Abstrak
Penelitian ini bertujuan untuk mengetahui keterlaksanaan penilaian autentik yang dilakukan oleh guru sosiologi kelas X di SMA Negeri 1 Lubuk Basung Tahun Ajaran 2019/2020. Metode dalam penelitian ini menggunakan pendekatan kuantitatif deskriptif dengan menerapkan model evaluasi stake's countenance. Teknik pengumpulan data yang digunakan adalah observasi, wawancara dan studi dokumentasi dengan teknik analisis data menggunakan metode konversi skor. Hasil dari penelitian ini adalah pelaksanaan penilaian autentik dalam pembelajaran sosiologi kelas X di SMA Negeri 1 Lubuk Basung sudah terlaksana dengan Baik, dengan perolehan rerata sebesar 3,0239 atau dalam persentase angka sebesar 77\% yang terdiri dari tiga tahapan evaluasi penilaian autentik diantaranya yaitu; tahap masukan dengan persentase sebesar $78 \%$, tahap proses dengan persentase sebesar $76 \%$, dan tahap hasil dengan persentase sebesar $76 \%$.
\end{abstract}

Kata Kunci: Autentik, Deskriptif, Kuantitatif, Penilaian

\section{Abstract}

This study aims to determine the implementation of authentic assessments carried out by class $X$ sociology teachers at SMA Negeri 1 Lubuk Basung Academic Year 2020/2021. The method in this study uses a descriptive quantitative approach by implementing an evaluation of the stake's countenance. The data collection techniques used were observation, interview and documentation study with the data analysis technique using the score conversion method. The result of this research is that the implementation of authentic assessment in class X sociology learning at SMA Negeri 1 Lubuk Basung has been carried out well, with a mean acquisition of 3.0239 or in a percentage of a figure of $77 \%$ consisting of three stages of evaluation of authentic assessment including; the input stage with a percentage of $78 \%$, the process stage with a percentage of $76 \%$, and the yield stage with a percentage of $76 \%$.

Keywords: Authentic, Descriptive, Quantitative, Assessment.

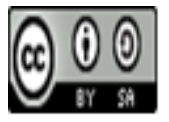

Received: October 15, 2020 Revised: November 11, 2020 Accepted: November 15, 2020

Jurnal Sikola: Jurnal Kajian Pendidikan dan Pembelajaran Vol. 2, No. 2, Th. 2020 


\section{Pendahuluan}

Pendidikan adalah salah satu alat yang sangat penting untuk meningkatkan daya saing dan mencari jati diri bagi setiap bangsa. Oleh karena itu, pemerintah harus memberikan fasilitas yang memadai untuk pelayanan pendidikan bermutu kepada setiap warga negaranya tanpa terkecuali, termasuk di dalamnya yang memiliki kebutuhan khusus (Putri \& Fernandes, 2019). Pendidikan nasional berfungsi mengembangkan kemampuan dan membentuk watak serta peradaban bangsa yang bermartabat dalam rangka mencerdaskan kehidupan bangsa (Alwidora \& Wirdanengsih, 2020).

Penilaian memegang peran penting dalam dunia pendidikan karena penilaian yang sesuai memberikan gambaran sejauh mana proses pembelajaran yang telah dilakukan dan dicapai oleh siswa. Penilaian juga dapat digunakan untuk mengetahui dan melihat apa yang harus dilakukan untuk meningkatkan dan mengembangkan kemampuan siswa (Puspitasari, 2016). Penilaian mempunyai pengaruh penting dalam proses belajar mengajar dan lingkungan pembelajaran serta memiliki peran untuk mengetahui hasil pembelajaran. Proses penilaian dalam pembelajaran dilakukan untuk memperoleh mengenai perkembangan hasil belajar peserta didik. Penilaian yang dilakukan diharapkan dapat menjadi instrument penjamin mutu, pengendalian mutu dan perbaikan mutu dalam sistem pendidikan baik secara kelas maupun sekolah (Sutama, Sandy, \& Fuadi, 2017)

Istilah penilaian memiliki pengertian yang lebih luas daripada sekedar pengukuran. penilaian sangatlah penting dan harus dilakukan oleh seorang guru, karena dengan melakukan penilaian seorang guru dapat melihat sejauh mana pemahaman dan perkembangan siswa didalam proses belajar mengajar. Penilaian bisa dilakukan pada saat sebelum kegiatan pembelajaran dimulai, ketika pembelajaran sedang berlangsung, dan di akhir kegiatan pembelajaran (Laelasari, 2017). Penilaian merupakan suatu kegiatan untuk memberikan gambaran berbagai informasi secara berkesinambungan dan menyeluruh yang berkaitan dengan aspek sikap, pengetahuan dan keterampilan tentang proses, serta hasil yang telah dicapai siswa (Laelasari, 2017).

Pelaksanaan proses pembelajaran dan melakukan penilaian proses serta hasil belajar adalah sebuah aktivitas yang tidak dapat dipisahkan, yang bertujuan agar dapat memantau kualitas pembelajaran dan memberikan feedback untuk perbaikan, sehingga perancangan strategi penilaian oleh pendidik sudah harus dibuat saat penyusunan rencana pelaksanaan pembelajaran (RPP) yang mengacu pada silabus. (Sylvia, Anwar, \& Khairani, 2019). Penilaian autentik dikembangkan dikarenakan penilaian yang selama ini digunakan mengabaikan konteks dunia nyata dan kurang menggambarkan kemampuan siswa secara holistic (Hadikusuma, 2016)

Upaya untuk meningkatkan kualitas pendidikan dapat dilakukan dengan peningkatan kualitas pembelajaran dan kualitas penilaiannya dalam proses pembelajaran (Ati et al., 2019). Kualitas pembelajaran dan kualitas penilaian merupakan dua hal yang saling berhubungan. Pembelajaran yang baik akan menghasilkan kualitas belajar yang baik, dan Kualitas pembelajaran ini dapat dilihat dari hasil penilaian. Sedangkan, penilaian yang baik dapat mendorong pendidik untuk menentukan strategi mengajar yang baik dan dapat memotivasi peserta didik untuk belajar dengan lebih baik. Oleh karena itu seorang pendidik harus memiliki kemampuan dan keterampilan mengenai bagaimana cara melaksanakan penilaian sesuai dengan standar penilaian yang telah ditetapkan. Penilaian sering diumpamakan sebagai salah satu dari tiga pilar utama yang menentukan kegiatan pembelajaran. Ketiga pilar tersebut adalah perencanaan, pelaksanaan, dan penilaian (Permatasari, 2013)

Untuk meningkatkan dan menciptakan kualitas pendidikan kearah yang lebih baik, di dalam Permendikbud Nomor 104 Tahun 2014 terdapat beberapa kriteria penilaian. Salah satu kriteria penilaian yang menjadi fokus utama dalam kurikulum 2013 adalah sistem penilaian autentik (authentic assessment). Sistem penilaian tersebut dianggap baik, karena dapat mendorong pendidik untuk mengajar lebih baik serta peserta didik untuk belajar lebih baik (Rosmawati \& Iriani, 2013).

Jurnal Sikola: Jurnal Kajian Pendidikan dan Pembelajaran Vol. 2, No. 2, Th. 2020 
Penilaian autentik merupakan penilaian yang dilakukan secara komprehensif untuk menilai mulai dari masukan (input), proses, dan keluaran (ouput) pembelajaran (Nahrowi, 2019). Penilaian autentik memiliki hubungan kuat terhadap pendekatan ilmiah dalam pembelajaran sesuai dengan tuntutan kurikulum 2013. Penilaian autentik adalah penilaian yang komprehensif, artinya mulai dari penilaian masukan (input), penilaian proses sampai penilaian output pembelajaran (Rizkiwati \& Farid, 2018). Penilaian autentik mengajarkan kepada peserta didik mengenai pembelajaran yang bermakna. Pembelajaran dengan menerapkan pengetahuan yang dimiliki oleh peserta didik ke dalam dunia nyata (Arif Amiruddin Jabbar, 2014). Authentic assessment merupakan salah satu asesmen hasil belajar yang menuntut peserta didik menunjukkan prestasi dan hasil belajar berupa ke-mampuan dalam kehidupan nyata dalam bentuk kinerja (Suprananto, 2012)

Penilaian Autentik berguna untuk mengetahui kemampuan dan ukuran keberhasilan peserta didik dalam belajar untuk mengetahui keberhasilan Aspek Sikap, Pengetahuan dan Keterampilan (Gahara, 2017). Dengan menerapkan penilaian autentik dalam pembelajaran sosiologi diharapkan dapat dapat memberi gambaran secara obyektif tentang bagaimana pelaksanaan penilaian autentik dalam pembelajaran, serta sebagai bahan refleksi pada penilaian autentik dalam pembelajaran yang sudah dilaksanakan sebelumnya (Pertiwi, 2009). Pelaksanaan Penilaian Autentik dapat meningkatkan pencapaian hasil belajar siswa karena dalam tugasnya diharuskan untuk aktif dan menggunakan semua aspek kompetensi yang dapat mengembangkan kemampuan siswa sehingga dapat menghasilkan pengaruh yang baik terhadap proses pembelajaran dan hasil belajar siswa. Penilaian adalah suatu upaya dan proses untuk menghimpun fakta-fakta dan dokumen belajar siswa yang dapat digunakan untuk melakukan perbaikan program pembelajaran.

Penelitian mengenai penilaian autentik yang dijelaskan di dalam penelitian ini berupa implementasi penilaian autentik yang dilakukan dan diterapkan oleh guru sosiologi di lapangan yang memiliki kewajiban melakukan suatu proses penilaian dari aspek sikap, aspek pengetahuan, dan aspek keterampilan. Supaya penelitian ini lebih terfokus, terarah, dan menghindari pembahasan yang meluas. Untuk itu peneliti membatasi masalah penelitian ini dan difokuskan pada pelaksanaan penilaian autentik yang terdiri dari penilaian sikap, pengetahuan dan keterampilan. Pelaksanaan penilaian autentik perlu untuk dievaluasi untuk mengetahui apakah penilaian hasil belajar sudah benar-benar terlaksana dengan baik atau belum. Berdasarkan batasan masalah penelitian yang telah di buat maka rumusan masalah dalam penelitian ini adalah Bagaimana Pelaksanaan Penilaian Autentik Dalam Pembelajaran Sosiologi Kelas X Semester Ganjil (Januari-Juni) Tahun Ajaran 2020/2021 di SMA Negeri 1 Lubuk Basung?

\section{Metode Penelitian}

Penelitian ini dilakukan di SMA Negeri 1 Lubuk Basung dan menggunakan metode kuantitatif deskriptif. Sejalan dengan namanya kuantitatif banyak dituntut menggunakan angka, mulai dari pengumpulan data, penafsiran terhadap data, serta dalam penampilan hasil (Dr. Ismael Nurdin, Dra. Sri Hartati, 2019). Penelitian ini menggunakan pendekatan stake countenans. Pendekatan stake countenans meliputi tiga komponen yaitu: Masukan, Proses, dan Hasil (Bendriyanti \& Dewi, n.d.). Penelitian berusaha mengukur dan melihat bagaimana pelaksanaan penilaian autentik dalam pembelajaran sosiologi kelas X di SMA Negeri 1 Lubuk Basung Semester Genap (Januari-Juni) Tahun Ajaran 2019/2020. Alasan peneliti memilih SMA Negeri 1 Lubuk Basung karena sekolah ini telah menerapkan kurikulum 2013 dalam proses pembelajaran serta sekolah ini merupakan sekolah favorit dan ter-akreditasi A serta ditunjuk sebagai sekolah piloting sekolah unggul pada Kecamatan Lubuk Basung, hal ini terbukti dengan berbagai prestasi dan penghargaan yang didapatkan dari tahun ke tahun.

Teknik pengumpulan data yang digunakan dalam penelitian ini adalah observasi, wawancara dan dokumentasi. Dalam teknik ini instrumen penelitian yang digunakan adalah lembar observasi. Observasi merupakan sebuah kegiatan melakukan pengamatan dengan

Jurnal Sikola: Jurnal Kajian Pendidikan dan Pembelajaran Vol. 2, No. 2, Th. 2020 
menggunakan panca indera (Indriana, 2018). Teknik ini digunakan dalam evaluasi yang dideskripsikan dengan pelaksanaan penilaian pembelajaran.

Teknik analisis data dalam penelitian ini menggunakan metode konversi skor, tujuannya ialah untuk memberikan gambaran ketercapaian pelaksanaan penilaian autentik pada setiap tahapannya selama proses pembelajaran sosiologi kelas X berlangsung.

\section{Hasil dan Pembahasan}

\section{Evaluasi Pelaksanaan Penilaian Autentik}

Evaluasi Pelakasanaan penilaian autentik pada mata pelajaran Sosiologi di SMA Negeri 1 Lubuk Basung dapat dilihat dari 3 Komponen pokok yaitu; Tahap Masukan, Tahap Proses, dan Tahap hasil. Pada ketiga tahap ealuasi tersebut, terdapar tiga kompetensi yang dapat dinilai yaitu penilaian kompetensi sikap, penilaian kompetensi pengetahuan, dan penilaian kompetensi keterampilan.

Pengolahan hasil penelitian dilakukan dengan memberikan skala persentase sesuai dengan kategori penilaian berdasarkan masing masing indicator evaluasi yang telah ditentukan. Data Hasil penelitian diolah untuk mengetahui skor rerata evaluasi pelaksanaan penilaian autentik dan persentase terlaksananya penilaian autentik di SMA Negeri 1 Lubuk Basung. Untuk mendapatkan gambaran lebih jelasnya perhatikan Tabel 1 berikut.

\section{Tabel 1. Evaluasi Keterlaksanaan Penilaian Autentik Model Stake}

\begin{tabular}{|c|c|c|c|c|c|c|}
\hline $\begin{array}{c}\text { Tahap } \\
\text { Evaluasi }\end{array}$ & $\begin{array}{l}\text { Komponen } \\
\text { Evalausi }\end{array}$ & $\begin{array}{c}\text { Jumlah } \\
\text { Indikator }\end{array}$ & $\begin{array}{c}\text { Jumlah } \\
\text { Skor } \\
\text { yang } \\
\text { diperoleh }\end{array}$ & $\begin{array}{c}\text { Skor } \\
\text { Rerata }\end{array}$ & $\begin{array}{c}\text { Hasil } \\
\text { Penilaian }\end{array}$ & Kategori \\
\hline \multirow{3}{*}{$\begin{array}{c}\text { Fase } \\
\text { Masukan } \\
\text { (Antecedents } \\
\text { Phase) }\end{array}$} & $\begin{array}{c}\text { Perencanaan } \\
\text { Penilaian } \\
\text { Sikap }\end{array}$ & 12 & 37 & 3,0833 & $77 \%$ & BAIK \\
\hline & $\begin{array}{l}\text { Perencanaan } \\
\text { Penilaian } \\
\text { Pengetahuan }\end{array}$ & 21 & 41 & 3,4166 & $85 \%$ & BAIK \\
\hline & $\begin{array}{l}\text { Perencanaan } \\
\text { Penilaian } \\
\text { Keterampilan }\end{array}$ & 11 & 32 & 2,9090 & $73 \%$ & BAIK \\
\hline \multicolumn{2}{|c|}{$\begin{array}{c}\text { Fase Masukan } \\
\text { (Antecedents Phase) }\end{array}$} & 35 & 110 & 3,1363 & $78 \%$ & BAIK \\
\hline \multirow[t]{3}{*}{$\begin{array}{c}\text { Fase Proses } \\
\text { (Transaction } \\
\text { Phase) }\end{array}$} & $\begin{array}{l}\text { Perencanaan } \\
\text { Penilaian } \\
\text { Sikap }\end{array}$ & 6 & 20 & 3,3333 & $83 \%$ & BAIK \\
\hline & $\begin{array}{l}\text { Perencanaan } \\
\text { Penilaian } \\
\text { Pengetahuan }\end{array}$ & 5 & 15 & 5 & $75 \%$ & BAIK \\
\hline & $\begin{array}{l}\text { Perencanaan } \\
\text { Penilaian } \\
\text { Keterampilan }\end{array}$ & 5 & 14 & 2,8 & $70 \%$ & BAIK \\
\hline \multicolumn{2}{|c|}{$\begin{array}{c}\text { Fase Proses (Transaction } \\
\text { Phase) } \\
\end{array}$} & 16 & 49 & 3,0444 & $76 \%$ & BAIK \\
\hline & $\begin{array}{l}\text { Perencanaan } \\
\text { Penilaian } \\
\text { Sikap }\end{array}$ & 8 & 26 & 3,25 & $81 \%$ & BAIK \\
\hline
\end{tabular}

Jurnal Sikola: Jurnal Kajian Pendidikan dan Pembelajaran Vol. 2, No. 2, Th. 2020 
Afrizal Muhardi, Ike Sylvia

Pelaksanaan Penilaian Autentik dalam Pembelajaran Sosiologi Kelas X Semester Ganjil (Januari-Juni) Tahun Ajaran 2020/2021 di SMA Negeri 1 Lubuk Basung

\begin{tabular}{ccccccc}
\hline $\begin{array}{c}\text { Fase Hasil } \\
\text { (Outcomes } \\
\text { Phase) }\end{array}$ & $\begin{array}{c}\text { Perencanaan } \\
\text { Penilaian } \\
\text { Pengetahuan }\end{array}$ & 8 & 23 & 2,875 & $71 \%$ & BAIK \\
\cline { 2 - 6 } & $\begin{array}{c}\text { Perencanaan } \\
\text { Penilaian } \\
\text { Keterampilan }\end{array}$ & 8 & 24 & 3 & $75 \%$ & BAIK \\
\hline Fase Hasil (Outcomes Phase) & $\mathbf{2 4}$ & $\mathbf{7 3}$ & $\mathbf{2 , 8 9 1}$ & $\mathbf{7 6 \%}$ & BAIK \\
\hline $\begin{array}{c}\text { Pelaksanaan Penilaian } \\
\text { Autentik }\end{array}$ & $\mathbf{7 5}$ & $\mathbf{2 3 2}$ & $\mathbf{3 , 0 2 3 9}$ & $\mathbf{7 7 \%}$ & BAIK \\
\hline
\end{tabular}

Sumber: Data yang diolah 2020

Secara keseluruhan apabila dilihat dari tabel 1 hasil evaluasi pelaksanaan penilaian autentik pada mata pelajara sosiologi di SMA Negeri 1 Lubuk Basung, secara umum pelaksanaannya sudah berjalan dengan baik, dengan persentase $77 \%$ dan jumlah rerata sebesar 3,0239 yang berarti pelaksanaan penilaian autentik yang dilaksanakan oleh guru sosiologi di SMA Negeri 1 Lubuk Basung termasuk dalam kategori baik.

Pada tabel 1 merupakan hasil analisis data yang diperoleh dari pengolahan data penelitian masing-masing perencanaan pada kompetensi sikap, perencanaan kompetensi pengetahuan, dan perencanaan kompetensi keterampilan. Berikut ini adalah gambaran yang menunjukan perolehan presentase sesuai dengan kompetensinya masing masing.

\section{Tahap Masukan/Pendahuluan (Antecendent Phase)}

Pada tahapan ini yang menjadi bagian dari proses evaluasi adalah perencanaan dan kesiapan guru mata pelajaran sosiologi untuk melakukan penilaian autentik dalam pembelajaran Sosiologi. Kesiapan Guru tersebut ditandai dengan lengkapnya perencanaan penilaian autentik Guru yang dituangkan dalam RPP dan silabus. Kemudian RPP dan Silabus tersebut merupakan data deskriptif yang diperoleh dari guru. Data deskriptif kemudian dibandingkan dengan standar yang ditentukan. Hasil dari perbandingan tersebut dapat menjelaskan apakah proses pelaksanaan penilaian autentik telah berjalan dengan baik atau belum. Untuk melihat bagaimana keterlaksanaan penilaian autentik fase masukan, perhatikan diagram 1 berikut.

\section{Penilaian Autentik - Fase Masukan}

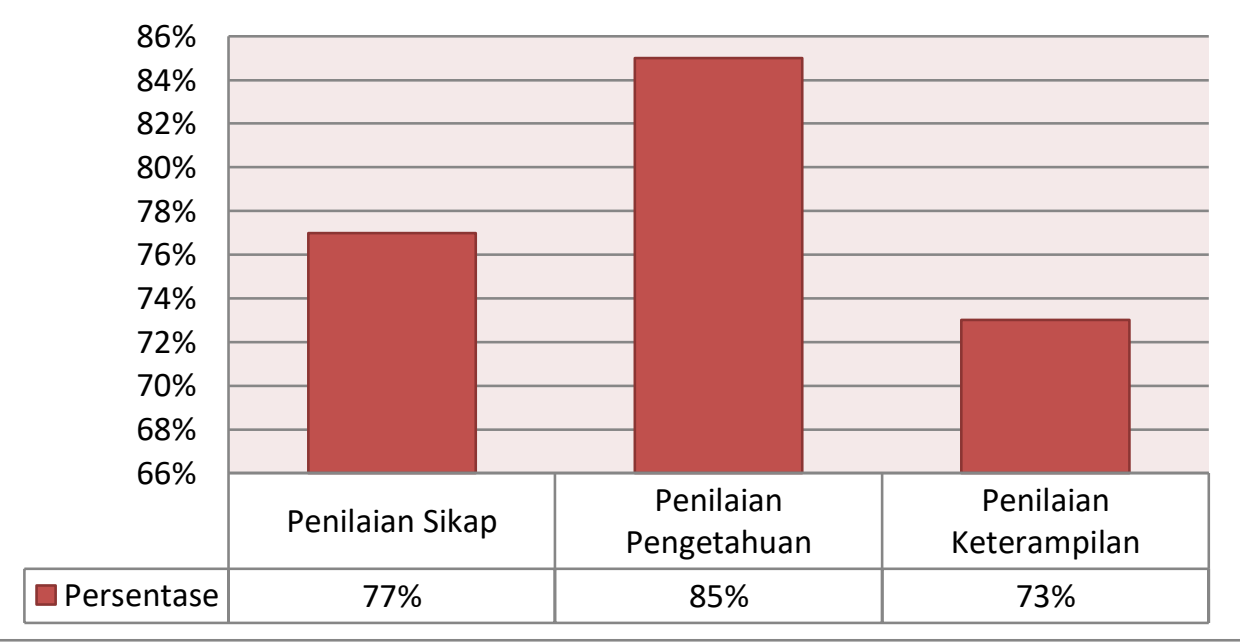

Gambar 1. Diagram Evaluasi Fase Masukan

Jurnal Sikola: Jurnal Kajian Pendidikan dan Pembelajaran Vol. 2, No. 2, Th. 2020 
Pada diagram 1 merupakan hasil analisis data yang diperoleh dari pengolahan data penelitian tahapan masukan, Berikut ini adalah gambaran yang menunjukan perolehan presentase sesuai dengan kompetensinya:

a) Perencanaan Penilaian Kompetensi Sikap

Pada Penilaian kompetensi sikap terdapar 12 indikator perencanaan penilaian sikap, karena rumusan indikator penilaian sikap terdapat penilaian budi pekerti, agama dan beberapa indicator untuk mementukan langkah dan instrumen pencapaian penilaian sikap.

Tabel 2. Hasil dan Tingkat Ketercapaian Evaluasi Perencanaan Penilaian Kompetensi Sikap

\begin{tabular}{cccccc} 
Evaluasi & $\begin{array}{c}\text { Jumlah } \\
\text { Indikator }\end{array}$ & $\begin{array}{c}\text { Jumlah } \\
\text { Skor yang } \\
\text { diperoleh }\end{array}$ & $\begin{array}{c}\text { Skor } \\
\text { Rerata }\end{array}$ & Hasil Penilaian & Kategori \\
\hline $\begin{array}{c}\text { Perencanaan } \\
\text { Penilaian Sikap }\end{array}$ & 12 & 37 & 3,0833 & $77 \%$ & BAIK \\
\hline
\end{tabular}

Sumber: Data yang diolah 2020

Jika dilihat dari Tabel 2 secara menyeluruh perencanaan perolehan penilaian kompetensi sikap memperoleh rerata sebesar 3,0833 dari skala 4 dan untuk persentase sebesar $77 \%$ dengan penggolongan kategori baik. Pada Tabel 2 membuktikan bahwa kesiapan guru sosiologi dalam melakukan penilaian autentik yang ditunjukan dari dokumen silabus dan RPP dalam pelaksanaan kompetensi sikap sudah sesuai dengan standar penilaian yang ada.

Guru Mata Pelajaran Sosiologi di SMA Negeri 1 Lubuk Basung sudah melaksanakan dengan Baik perencanaan penilaian kompetensi sikap, kaena sudah dibuktikan dengan persentase pencapaian evaluasi pelaksanaan penilaian kompetensi sikap sebesar 77\% dengan Kategori Baik. Dalam menyusun RPP Guru sudah berpedoman kepada buku guru serta dari pelatihan dinas pendidikan secara khusus membahasan tentang penyusunan RPP dengan baik dan benar (MGMP Sosiologi) berdasarkan Permendikbud yang berlaku.

b) Perencanaan Penilaian Kompetensi Pengetahuan

Tabel 3. Hasil dan Tingkat Ketercapaian Evaluasi Perencanaan Penilaian Kompetensi Pengetahuan

\begin{tabular}{cccccc}
\hline Evaluasi & $\begin{array}{c}\text { Jumlah } \\
\text { Indikator }\end{array}$ & $\begin{array}{c}\text { Jumlah } \\
\text { Skor yang } \\
\text { diperoleh }\end{array}$ & $\begin{array}{c}\text { Skor } \\
\text { Rerata }\end{array}$ & $\begin{array}{c}\text { Hasil } \\
\text { Penilaian }\end{array}$ & Kategori \\
\hline $\begin{array}{c}\text { Perencanaan } \\
\begin{array}{c}\text { Penilaian } \\
\text { Pengetahuan }\end{array}\end{array}$ & 12 & 41 & 3,4166 & $85 \%$ & BAIK \\
\hline
\end{tabular}

Sumber: Data yang diolah 2020

Tabel 3 diatas menjelaskan bahwa keterlaksanaan perencanaan pelaksanaan penilaian kompetensi pengetahuan pada pembelajaran sosiologi yang dilakukan oleh guru sosiologi di SMA Negeri 1 Lubuk Basung dari hasil analisis dokumentaasi dengan membandingkan dengan standar yang ada. Pada Tabel diatas dapat disimpulkan bahwa hasil evaluasi anaan pelaksanaan penilaian kompetensi pengetahuan memperoleh persentase $85 \%$ atau perolehan skor rerata penilaian kompetensi pengetahuan sebesar 3,4166 dari skala 4 dengan Kategori Baik. 
Pelaksanaan penilaian kompetensi pengetahuan dalam proses evaluasi ini meliputi komponen; 1) Rancangan Penilaian Pengetahuan, 2) Indikator Pencapaian Kompetensi Pengetahuan, 3) Teknik dan Instrumen Penilaian Pengetahuan, 4) Cara pengolahan Penilaian Pengetahuan. Dari beberapa komponen tersebut kemudian dijelaskan ke dalam Tabel 3 yang yang menggambarkan standar pelaksanaan penilaian kompetensi pengetahuan mata pelajaran sosiologi.

c) Perencanaan Penilaian Kompetensi Keterampilan

Tabel 4. Hasil dan Tingkat Ketercapaian Evaluasi Perencanaan Penilaian Kompetensi Keterampilan

\begin{tabular}{cccccc}
\hline Evaluasi & $\begin{array}{c}\text { Jumlah } \\
\text { Indikator }\end{array}$ & $\begin{array}{c}\text { Jumlah } \\
\text { Skor yang } \\
\text { diperoleh }\end{array}$ & Skor Rerata & $\begin{array}{c}\text { Hasil } \\
\text { Penilaian }\end{array}$ & Kategori \\
\hline $\begin{array}{c}\text { Perencanaan } \\
\text { Penilaian } \\
\text { Keterampilan }\end{array}$ & 11 & 32 & 2,9090 & $73 \%$ & BAIK \\
\hline
\end{tabular}

Sumber: Data yang diolah 2020

Evaluasi perencanaan penilaian keterampilan yang dilaksanakan oleh guru merupakan tahapan awal yang berusaha menjelaskan integrasi kegiatan proses pembelajaran dengan penilaian. Evaluasi perencanaan penilaian keterampilan dalam penelitian meliputi beberapa komponen yaitu; 1) Rancangan penilaian keterampilan, 2) indikator pencapaian kompetensi keterampilan, 3) teknik dan instrument penilaian keterampilan, 4) proses pengolahan penilaian keterampilan.

Secara umum, jika dilihat dari Tabel 4, Evaluasi perencanaan penilaian keterampilan memperoleh skor rerata 2,9090 dari skala 4 atau dalam persentase mendapatkan $73 \%$ dengan Kategori keterlaksanaan Baik. Hal ini menunjukan bahwa kesiapan guru dalam menjalankan penilaian autentik yang ditunjukan dari dokumen RPP dan Silabus dalam kompetensi keterampilan sudah sesuai dan berjalan sesuai dengan standard yang ada.

Untuk melihat bagaimana keterlaksanaan Perencanaan Penilaian Autentik pada Tahapan Masukan yang telah dievaluasi yang terdiri dari Perencanaan Penilaian Sikap, Perencanaan Penilaian Pengetahuan, Perencanaan Penilaian Keterampilan dapat dilihat pada Tabel 5 berikut.

Tabel 5. Hasil dan Tingkat Ketercapaian Evaluasi Tahap Masukan

\begin{tabular}{ccccccc}
\hline No & Evaluasi & $\begin{array}{c}\text { Jumlah } \\
\text { Indikator }\end{array}$ & $\begin{array}{c}\text { Jumlah } \\
\text { Skor yang } \\
\text { diperoleh }\end{array}$ & $\begin{array}{c}\text { Skor } \\
\text { Rerata }\end{array}$ & $\begin{array}{c}\text { Hasil } \\
\text { Penilaian }\end{array}$ & Kategori \\
\hline $\mathbf{1}$ & $\begin{array}{c}\text { Perencanaan } \\
\text { Penilaian Sikap }\end{array}$ & 12 & 37 & 3,0833 & $77 \%$ & BAIK \\
\hline $\mathbf{2}$ & $\begin{array}{c}\text { Perencanaan } \\
\text { Penilaian } \\
\text { Pengetahuan }\end{array}$ & 12 & 41 & 3,4166 & $85 \%$ & BAIK \\
\hline $\mathbf{3}$ & $\begin{array}{c}\text { Perencanaan } \\
\text { Penilaian } \\
\text { Keterampilan }\end{array}$ & 11 & 32 & 2,9090 & $73 \%$ & BAIK \\
\hline & & $\mathbf{1 1 0}$ & $\mathbf{3 , 1 3 6 3}$ & $\mathbf{7 8 \%}$ & BAIK \\
\hline
\end{tabular}

Sumber: Data yang diolah 
Berdasarkan Tabel 5 diatas dijelaskan bahwa pelaksanaan penilaian autentik pada Tahapan Masukan sudah berjalan dengan baik oleh guru mata pelajaran sosiologi di SMA Negeri 1 Lubuk Basung. Pada tahapan ini Perencanaan Penilaian Pengetahuan mendapatkan Skor Rerata tertinggi yakni sebesar 3,4166, kemudian diikuti oleh Perencanaan Penilaian Sikap yang memperoleh Skor Rerata sebesar 3,0833, dan diurutan terendah Perencanaan Penilaian Keterampilan memperoleh Skor Rerata sebesar 2,9090, jika dilihat dari rerata Tingkat Ketercapaian Evaluasi Tahap Masukan berjumlah 3,1363 dalam skala 4 dan dalam jumlah persentase memperoleh angka 78\%. Oleh karena itu, hasil evaluasi Pelaksanaan Penilaian Autentik Tahap Masukan ini dapat dikategorikan Baik.

Secara umum, Tabel 5 menjelaskan bahwa Guru Sosiologi di SMA Negeri 1 Lubuk Basung melaksanakan Penilaian Autentik sudah Baik dalam mengembangkan Perencanaan Penilaian Autentik dalam rangka implementasi dilapangan. Secara keseluruhan Perencanaan Penilaian Sikap, Perencanaan Penilaian Pengetahuan, dan Perencanaan Penilaian Keterampilan sudah memenuhi standar penilaian.

\section{Fase Proses (Transaction Phase)}

Pada Fase Proses ini yang menjadi fokus pelaksanaan penilaian autentik melalui observasi langsung dalam proses pembelajaran ialah mengenai bagaimana penginformasian sistem penilaian dan pelaksanaan penilaian autentik yang sesuai dengan rencana penelitian. Pelaksanaan penilaian autentik dilakukan dengan memperhatikan tigas aspek penilaian, yaitu; penilaian sikap, penilaian pengetahuan dan penilaian keterampilan.

Pada Diagram 2 dibawah ini menunjukan bagaimana perolehan hasil observasi pelaksanaan penilaian Fase Proses (Transaction Phase) yang akan menunjukan bagaimana pelaksanaan kesesuaian penilaian yang telah dilakukan dengan standar yang ada.

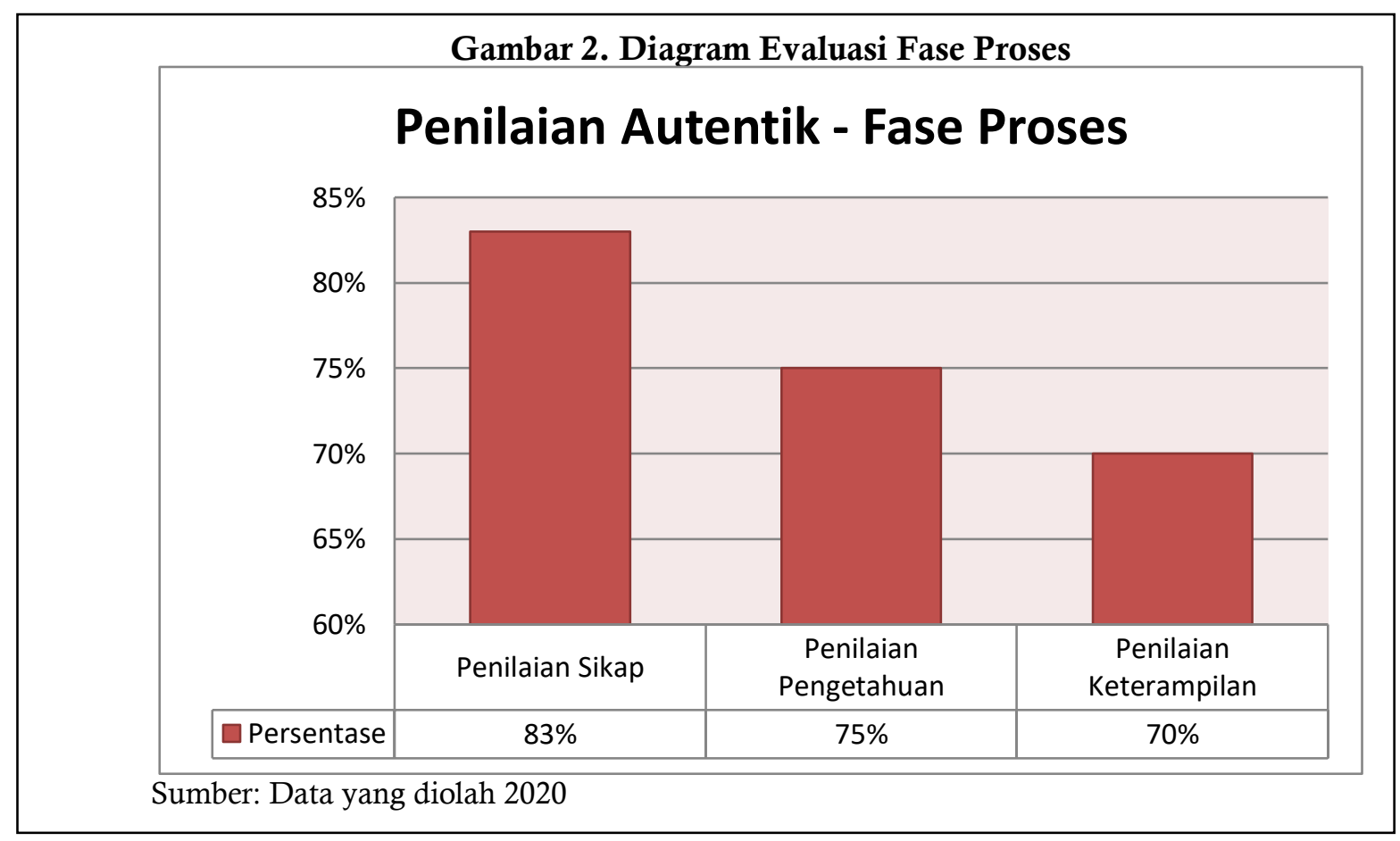

Pada Diagram 2 diatas merupakan hasil analisis data yang diperoleh dari pengolahan data penelitian Tahapan Proses, Berikut ini adalah gambaran yang menunjukan perolehan presentase sesuai dengan kompetensinya: 
a) Perencanaan Penilaian Kompetensi Sikap

Pelaksanaan Penilaian sikap dilaksanakan selama proses belajar mengajar berlangsung, penilaian sikap dilaksanakan menggunakan instrumen lembar pengamatan yang sudah direncakan dalam rencana pelaksanaan pembelajaran dan penelitian yaitu; pelaksanaan penilaian sikap meliputi jenis penilaian, teknik penilaian bentuk tes, dan tata cara penilaian.

Pelaksanaan penilaian sikap meliputi komponen 1) Menginformasikan tata cara penilaian sikap, 2) tata cara pelaksanaan penilaian sikpa secara efektif. Dari komponen penilaian sikap tersebut dapat dijabarkan menjadi penyataan lebih rinci, penyataan tersebut menggambarkan dan menjelaskan bagaimana pelaksanaan penilaian auentik yang sesuai dengan tuntutan kurikulum yang telah dimuat dalam lembar observasi. Untuk melihat olahan hasil Pelaksanaan Penilaian sikap dapat dilihat Tabel 6.

Tabel 6. Hasil dan Tingkat Ketercapaian Evaluasi Proses Penilaian Kompetensi Sikap

\begin{tabular}{cccccc}
\hline Evaluasi & $\begin{array}{c}\text { Jumlah } \\
\text { Indikator }\end{array}$ & $\begin{array}{c}\text { Jumlah Skor } \\
\text { yang } \\
\text { diperoleh }\end{array}$ & Skor Rerata & $\begin{array}{c}\text { Hasil } \\
\text { Penilaian }\end{array}$ & Kategori \\
\hline $\begin{array}{c}\text { Perencanaan } \\
\text { Penilaian Sikap }\end{array}$ & 6 & 20 & 3,3333 & $83 \%$ & BAIK \\
\hline
\end{tabular}

Sumber : Data yang diolah

Sesuai dengan Tabel 6, dapat disimpulkan bahwa pelaksanaan penilaian kompetensi sikpa memperoleh skor rerata sebesar 3,3333 dari skala 4 atau dalam persentase memperoleh angka $83 \%$ yang dapat diklasifikasikan kedalam Kategori Baik.

b) Perencanaan Penilaian Kompetensi Pengetahuan

Pelaksanaan Perencanaan Penilaian Kompetensi Pengetahuan dilakukan sebelum, selama, dan sesudah proses pembelajaran berlangsung. Pelaksanaan sebelum pembelajaran dilakukan dengan memberikan pertanyaan-pertanyaan yang berhubungan dengan materi yang akan dipelajari, Perlaksanaan Penilaian selama proses pembelajaran dilakukan dengan memberikan soal-soal latihan, diskusi kelompok, debat,dll, Sedangkan Penilaian yang dilakukan pada akhir permbelajaran diberikan tugas tertulis untuk melihat sejauh mana kemampuan peserta didik setelah mengikuti pembelajaran.

Pelaksanaan Perencanaan Penilaian Kompetensi Pengetahuan dalam penelitian meliputi 2 komponen penting, yaitu; 1) Menginformasikan Sistem Penilaian, 2) Melaksanakan Penilaian dengan efektif. Dari 2 Komponen tersebut dapat diuraikan menjadi pernyataan yang lebih rinci. Pernyataan tersebut menjelaskan standard pelaksanaan penilaian pengetahuan sesuai dengan kurikulum dan dimasukan kedalam lembar observasi. Perolehan olahan data dari evaluasi pelaksanaan penilaian pengetauan yang berlansung selama proses pembelajaran untuk lebih jelasnya dapat melihat Tabel 7 dibawah ini.

Tabel 7. Hasil dan Tingkat Ketercapaian Evaluasi Proses Penilaian Kompetensi Pengetahuan

\begin{tabular}{cccccc}
\hline Evaluasi & $\begin{array}{c}\text { Jumlah } \\
\text { Indikator }\end{array}$ & $\begin{array}{c}\text { Jumlah } \\
\text { Skor yang } \\
\text { diperoleh }\end{array}$ & $\begin{array}{c}\text { Skor } \\
\text { Rerata }\end{array}$ & $\begin{array}{c}\text { Hasil } \\
\text { Penilaian }\end{array}$ & Kategori \\
\hline $\begin{array}{c}\text { Perencanaan } \\
\text { Penilaian } \\
\text { Pengetahuan }\end{array}$ & 5 & 15 & 3 & $75 \%$ & BAIK \\
\hline
\end{tabular}

Sumber : Data yang diolah

Jurnal Sikola: Jurnal Kajian Pendidikan dan Pembelajaran Vol. 2, No. 2, Th. 2020 
Berdasarkan dengan Tabel 7, dapat disimpulkan bahwa pelaksanaan penilaian kompetensi pengetahuan memperoleh skor rerata sebesar 3 dari skala 4 atau dalam persentase memperoleh angka $75 \%$ yang mana Evaluasi pelaksanaan Perencanaan Penilaian Kompetensi Pengetahuan di SMA Negeri 1 Lubuk Basung berjalan dan termasuk kedalam Kategori Baik.

c) Perencanaan Penilaian Kompetensi Keterampilan

Pelaksanaan penilaian keterampilan adalah tahap penerapan dari sebuah proses perencanaan yang sudah dibuat sebelumnya. Pelaksanaan penilaian keterampilan dalam penelitian ini meliputi beberapa komponen, yaitu; 1) Menginformasikan system penilaian keterampilan, 2) Melaksanakan Penilaian keterampilan dengan efektif. Dari komponen tersebut dapat dijelaskan menjadi pernyataan yang lebih rinci, pernyataan tersebut menggambarkan standard pelaksanaan penilaian keterampilan yang sesuai dengan tuntutan kurikulum dan dimasukan kedalam lembar observasi. Untuk melihat hasil olahan data dari Perencanaan Penilaian Kompetensi Keterampilan dapat dilihat pada Tabel 8.

Tabel 8. Hasil dan Tingkat Ketercapaian Evaluasi Proses Penilaian Kompetensi Keterampilan

\begin{tabular}{cccccc}
\hline Evaluasi & $\begin{array}{c}\text { Jumlah } \\
\text { Indikator }\end{array}$ & $\begin{array}{c}\text { Jumlah Skor } \\
\text { yang } \\
\text { diperoleh }\end{array}$ & Skor Rerata & $\begin{array}{c}\text { Hasil } \\
\text { Penilaian }\end{array}$ & Kategori \\
\hline $\begin{array}{c}\text { Perencanaan } \\
\text { Penilaian } \\
\text { Keterampilan }\end{array}$ & 5 & 14 & 2,8 & $70 \%$ & BAIK \\
\hline
\end{tabular}

Sumber: Data yang diolah

Berdasarkan Tabel 8, Pelaksanaan Perencanaan Penilaian Kompetensi Keterampilan memperoleh skor rerata sebesar 2,8 dari skala 4 atau dalam jumlah persentase memperoleh angka sebesar 70\%. Evaluasi pelaksanaan Perencanaan Penilaian Kompetensi Keterampilan di SMA Negeri 1 Lubuk Basung berjalan dan termasuk kedalam Kategori Baik.

Secara keseluruhan komponen yang sudah dievaluasi pada fase prosesdapat diperoleh gambaran mengenai keterlaksanaan penilaian autentik dalam proses pembelajaran sosiologi kelas X di SMA Negri 1 Lubuk Basung. Pada Fase Proses ini pelaksanaan penilaian terdiri dari penilaian sikap, penilaian pengetahuan, dan penilaian keterampilan. Untuk lebih jelasnya dapat dengan melihat Tabel 9 berikut.

Tabe1 9. Hasil dan Tingkat Ketercapaian Evaluasi Fase Proses

\begin{tabular}{ccccccc}
\hline No & Evaluasi & $\begin{array}{c}\text { Jumlah } \\
\text { Indikator }\end{array}$ & $\begin{array}{c}\text { Jumlah Skor } \\
\text { yang diperoleh }\end{array}$ & $\begin{array}{c}\text { Skor } \\
\text { Rerata }\end{array}$ & Hasil Penilaian & Kategori \\
\hline $\mathbf{1}$ & $\begin{array}{c}\text { Perencanaan } \\
\text { Penilaian Sikap }\end{array}$ & 6 & 20 & 3,3333 & $83 \%$ & BAIK \\
\hline $\mathbf{2}$ & $\begin{array}{c}\text { Perencanaan } \\
\text { Penilaian } \\
\text { Pengetahuan }\end{array}$ & 5 & 15 & 3 & $75 \%$ & BAIK \\
\hline $\mathbf{3}$ & $\begin{array}{c}\text { Perencanaan } \\
\text { Penilaian } \\
\text { Keterampilan }\end{array}$ & 5 & 14 & 2,8 & $70 \%$ & BAIK \\
\hline & Fase Proses & $\mathbf{1 6}$ & $\mathbf{4 9}$ & $\mathbf{3 , 0 4 4 4}$ & $\mathbf{7 6 \%}$ & BAIK \\
\hline
\end{tabular}

Sumber : Data yang diolah

Jurnal Sikola: Jurnal Kajian Pendidikan dan Pembelajaran Vol. 2, No. 2, Th. 2020 
Pada Tabel 9 diatas, menggambarkan bagaimana ketercapaian penilaian autentik pada Fase Proses. Pelaksanaan penilaian autentik fase proses di SMA Negeri 1 Lubuk sudah berjalan dengan Baik. Dapat dilihat dari seluruh tahapan proses, baik dari segi penilaian sikap, penilaian pengetahuan dan penilaian keterampilan sudah memenuhi standard yang ada.

Pada tahapan ini Perencanaan Penilaian Sikap mendapatkan Skor Rerata tertinggi yakni sebesar 3,3333, kemudian diikuti oleh Perencanaan Penilaian Pengetahuan yang memperoleh Skor Rerata sebesar 3, dan diurutan terendah Perencanaan Penilaian Keterampilan memperoleh Skor Rerata sebesar 2,8 dalam skala 4, jika dilihat dari rerata Tingkat Ketercapaian Evaluasi Tahap Masukan berjumlah 3,0444 dalam skala 4 dan dalam jumlah persentase memperoleh angka 76\%. Oleh karena itu, hasil evaluasi Pelaksanaan Penilaian Autentik Tahap Masukan ini dapat dikategorikan Baik.

\section{Fase Hasil (Outcomes Phase)}

Fase Hasil adalah tahapan dimana evaluasi yang dilakukan oleh guru melalui manajemen hasil penilaian yang dilakukan dengan cara mengamati hasil observasi terhadap siswa, Evaluasi Hasil adalah cara untuk melihat, mengukur dan mengartikan terhadap hasil yang telah dicapai dari sebuah program penilaian. Komponen evaluasi hasil dalam penelitian ini terdiri dari penilaian sikap, penilaian pengetahuan, dan penilaian keterampilan.

Untuk melihat bagaimana keterlaksanaan Perencanaan Penilaian Autentik pada Tahapan Hasil yang telah dievaluasi yang terdiri dari Perencanaan Penilaian Sikap, Perencanaan Penilaian Pengetahuan, Perencanaan Penilaian Keterampilan dapat dilihat pada Diagram 3 berikut.

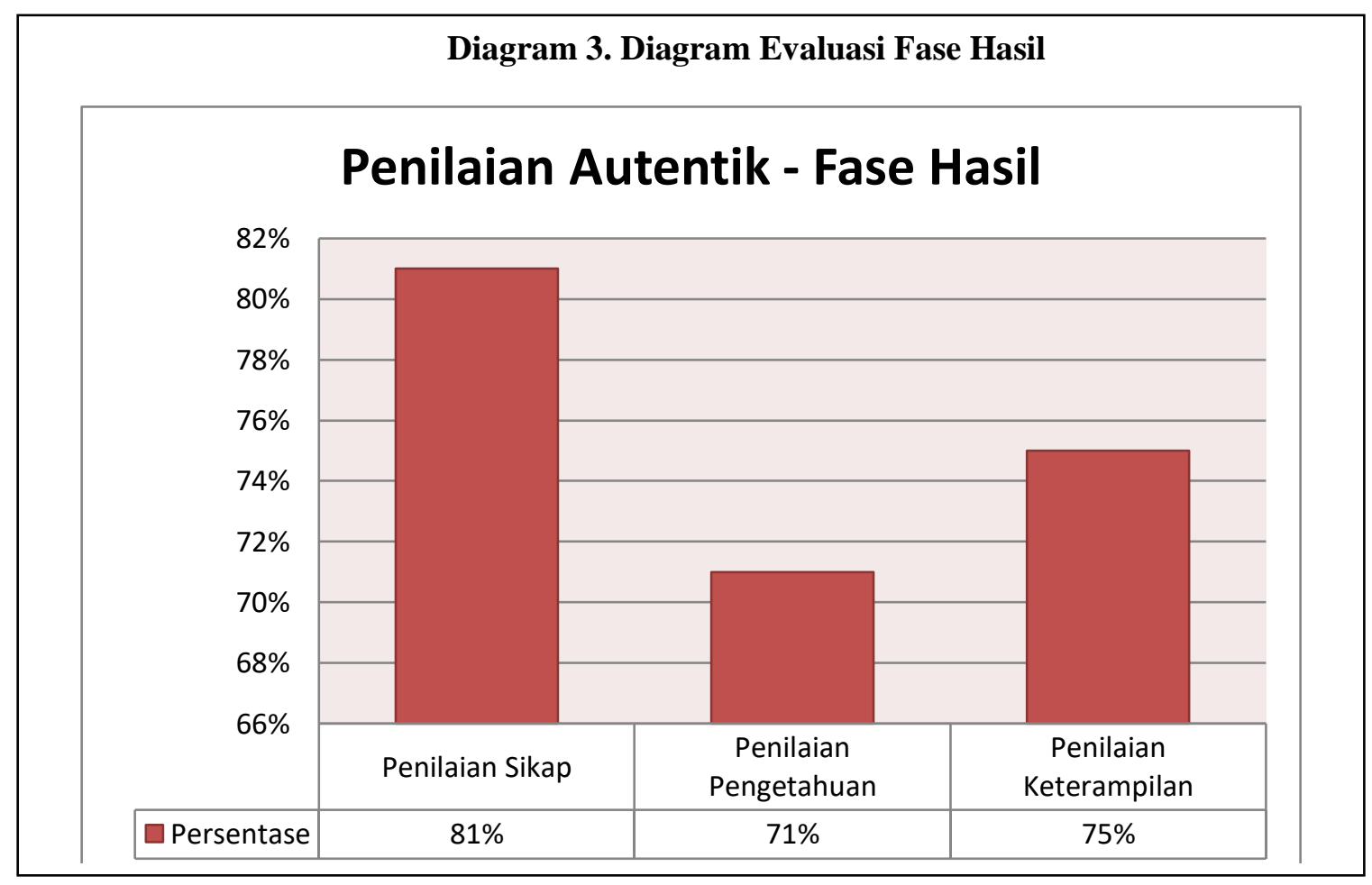

Pada Diagram 3 diatas merupakan hasil analisis data yang diperoleh dari pengolahan data penelitian Tahapan Hasil, Berikut ini adalah gambaran yang menunjukan perolehan presentase sesuai dengan kompetensinya 
a) Perencanaan Penilaian Kompetensi Sikap

Perencanaan Penilaian Kompetensi Sikap dilaksanakan untuk melihat sikap siswa selama proses belajar mengajar berlangsung didalam kelas. Adapun komponen dari penilaian sikap ini adalah; 1) Bagaimana cara pengelolaan Sikap, 2) Laporan mengenai penilaian sikap, dan 3) Tindak lanjut dari penilaian sikap. Dari komponen penilaian sikap tersebut dapat dijabarkan menjadi penyataan lebih kompleks, penyataan tersebut menggambarkan dan menjelaskan bagaimana pelaksanaan penilaian autentik yang sesuai dengan tuntutan kurikulum yang telah dimuat dalam lembar observasi. Untuk melihat olahan hasil Pelaksanaan Penilaian sikap dapat dilihat Tabel 10.

Tabel 10. Hasil dan Tingkat Ketercapaian Evaluasi Hasil Penilaian Kompetensi Sikap

\begin{tabular}{cccccc} 
Evaluasi & $\begin{array}{c}\text { Jumlah } \\
\text { Indikator }\end{array}$ & $\begin{array}{c}\text { Jumlah Skor } \\
\text { yang } \\
\text { diperoleh }\end{array}$ & Skor Rerata & $\begin{array}{c}\text { Hasil } \\
\text { Penilaian }\end{array}$ & Kategori \\
\hline $\begin{array}{c}\text { Perencanaan } \\
\text { Penilaian Sikap }\end{array}$ & 8 & 26 & 2,8 & $81 \%$ & BAIK \\
\hline
\end{tabular}

Sumber : Data yang diolah

Tabel 10 diatas menjelaskan bahwa keterlaksanaan perencanaan pelaksanaan penilaian kompetensi sikap pada pembelajaran sosiologi yang dilakukan oleh guru sosiologi di SMA Negeri 1 Lubuk Basung dari hasil analisis dokumentaasi dengan membandingkan dengan standar yang ada. Pada Tabel diatas dapat disimpulkan bahwa hasil evaluasi anaan pelaksanaan penilaian kompetensi pengetahuan memperoleh persentase $81 \%$ atau perolehan skor rerata penilaian kompetensi pengetahuan sebesar 3,4166 dari skala 4 dengan Kategori Baik.

b) Perencanaan Penilaian Kompetensi Pengetahuan

Perencanaan Penilaian Kompetensi Pengetahuan dilaksanakan untuk melihat dan menentukan hasil dari kemampuan pengetahuan siswa selama proses belajar mengajar berlangsung didalam kelas. Adapun komponen dari penilaian sikap ini adalah; 1) Bagaimana cara pengelolaan Sikap, 2) Laporan mengenai penilaian sikap, dan 3) Tindak lanjut dari penilaian sikap. Dari komponen penilaian sikap tersebut dapat dijabarkan menjadi penyataan lebih kompleks, penyataan tersebut menggambarkan dan menjelaskan bagaimana pelaksanaan penilaian autentik yang sesuai dengan tuntutan kurikulum yang telah dimuat dalam lembar observasi. Untuk melihat olahan hasil Pelaksanaan Penilaian sikap dapat dilihat Tabel 11.

Tabel 11. Hasil dan Tingkat Ketercapaian Evaluasi Hasil Penilaian Kompetensi Pengetahuan

\begin{tabular}{cccccc} 
Evaluasi & $\begin{array}{c}\text { Jumlah } \\
\text { Indikator }\end{array}$ & $\begin{array}{c}\text { Jumlah } \\
\text { Skor yang } \\
\text { diperoleh }\end{array}$ & Skor Rerata & $\begin{array}{c}\text { Hasil } \\
\text { Penilaian }\end{array}$ & Kategori \\
\hline $\begin{array}{c}\text { Perencanaan } \\
\text { Penilaian } \\
\text { Pengetahuan }\end{array}$ & 8 & 23 & 2,875 & $71 \%$ & BAIK \\
\hline
\end{tabular}

Sumber : Data yang diolah

Tabel 11 diatas menjelaskan bahwa keterlaksanaan perencanaan pelaksanaan penilaian kompetensi Pengetahuan pada pembelajaran sosiologi yang dilakukan oleh guru sosiologi di SMA Negeri 1 Lubuk Basung dari hasil analisis Observasi dengan membandingkan dengan standar yang

Jurnal Sikola: Jurnal Kajian Pendidikan dan Pembelajaran Vol. 2, No. 2, Th. 2020 
ada. Pada Tabel diatas dapat disimpulkan bahwa hasil evaluasi anaan pelaksanaan penilaian kompetensi pengetahuan memperoleh persentase $71 \%$ atau perolehan skor rerata penilaian kompetensi pengetahuan sebesar 2,875 dari skala 4 dengan Kategori Baik.

c) Perencanaan Penilaian Kompetensi Keterampilan

Perencanaan Penilaian Kompetensi Keterampilan dilaksanakan untuk melihat dan menentukan hasil dari kemampuan keterampilan siswa selama proses belajar mengajar berlangsung didalam kelas. Adapun komponen dari penilaian sikap ini adalah; 1) Bagaimana cara pengelolaan Sikap, 2) Laporan mengenai penilaian sikap, dan 3) Tindak lanjut dari penilaian sikap. Dari komponen penilaian sikap tersebut dapat dijabarkan menjadi penyataan lebih kompleks, penyataan tersebut menggambarkan dan menjelaskan bagaimana pelaksanaan penilaian autentik yang sesuai dengan tuntutan kurikulum yang telah dimuat dalam lembar observasi. Untuk melihat olahan hasil Pelaksanaan Penilaian sikap dapat dilihat Tabel 12.

Tabel 12. Hasil dan Tingkat Ketercapaian Evaluasi Hasil Penilaian Kompetensi Keterampilan

\begin{tabular}{cccccc}
\hline Evaluasi & $\begin{array}{c}\text { Jumlah } \\
\text { Indikator }\end{array}$ & $\begin{array}{c}\text { Jumlah } \\
\text { Skor yang } \\
\text { diperoleh }\end{array}$ & Skor Rerata & $\begin{array}{c}\text { Hasil } \\
\text { Penilaian }\end{array}$ & Kategori \\
\hline $\begin{array}{c}\text { Perencanaan } \\
\text { Penilaian } \\
\text { Keterampilan }\end{array}$ & 8 & 24 & 3 & $75 \%$ & BAIK \\
\hline
\end{tabular}

Sumber : Data yang diolah

Tabel 12 diatas menjelaskan bahwa keterlaksanaan perencanaan pelaksanaan penilaian kompetensi Keterampilan pada pembelajaran sosiologi yang dilakukan oleh guru sosiologi di SMA Negeri 1 Lubuk Basung dari hasil analisis Observasi dengan membandingkan dengan standar yang ada. Pada Tabel diatas dapat disimpulkan bahwa hasil evaluasi anaan pelaksanaan penilaian kompetensi Keterampilan memperoleh persentase $75 \%$ atau perolehan skor rerata penilaian kompetensi pengetahuan sebesar 3 dari skala 4 dengan Kategori Baik.

Secara keseluruhan komponen yang sudah dievaluasi pada fase hasil dapat diperoleh gambaran mengenai keterlaksanaan penilaian autentik dalam proses pembelajaran sosiologi kelas X di SMA Negri 1 Lubuk Basung. Pada Fase hasil ini pelaksanaan penilaian terdiri dari penilaian sikap, penilaian pengetahuan, dan penilaian keterampilan. Untuk lebih jelasnya dapat dengan melihat Tabel 13 berikut.

Tabel 13. Hasil dan Tingkat Ketercapaian Evaluasi Fase Hasil

\begin{tabular}{ccccccc}
\hline No & Evaluasi & $\begin{array}{c}\text { Jumlah } \\
\text { Indikator }\end{array}$ & $\begin{array}{c}\text { Jumlah } \\
\text { Skor yang } \\
\text { diperoleh }\end{array}$ & $\begin{array}{c}\text { Skor } \\
\text { Rerata }\end{array}$ & $\begin{array}{c}\text { Hasil } \\
\text { Penilaian }\end{array}$ & Kategori \\
\hline $\mathbf{1}$ & $\begin{array}{c}\text { Perencanaan } \\
\text { Penilaian Sikap }\end{array}$ & 8 & 26 & 3,25 & $81 \%$ & BAIK \\
\hline $\mathbf{2}$ & $\begin{array}{c}\text { Perencanaan } \\
\text { Penilaian } \\
\text { Pengetahuan }\end{array}$ & 8 & 23 & 2,875 & $71 \%$ & BAIK \\
\hline
\end{tabular}


Afrizal Muhardi, Ike Sylvia Pelaksanaan Penilaian Autentik dalam Pembelajaran Sosiologi Kelas X Semester Ganjil (Januari-Juni) Tahun Ajaran 2020/2021 di SMA Negeri 1 Lubuk Basung

\begin{tabular}{ccccccc}
\hline 3 & $\begin{array}{c}\text { Perencanaan } \\
\text { Penilaian } \\
\text { Keterampilan }\end{array}$ & 8 & 24 & 3 & $75 \%$ & BAIK \\
\hline Fase Hasil & $\mathbf{2 4}$ & $\mathbf{7 3}$ & $\mathbf{3 , 0 4 1}$ & $\mathbf{7 6 \%}$ & BAIK \\
\hline
\end{tabular}

Sumber : Data yang diolah

Pada Tabel 13 diatas, menggambarkan bagaimana ketercapaian penilaian autentik pada Fase Hasil. Pelaksanaan penilaian autentik fase Hasil di SMA Negeri 1 Lubuk sudah berjalan dengan Baik. Dapat dilihat dari seluruh tahapan proses, baik dari segi penilaian sikap, penilaian pengetahuan dan penilaian keterampilan sudah memenuhi standard yang ada. Pada tahapan ini Perencanaan Penilaian Sikap mendapatkan Skor Rerata tertinggi yakni sebesar 3,25 kemudian diikuti oleh Perencanaan Penilaian Keterampilan yang memperoleh Skor Rerata sebesar 3 dan Perencanaan Penilaian Pengetahuan yang memperoleh Skor Rerata sebesar 2,875, jika dilihat dari rerata Tingkat Ketercapaian Evaluasi Tahap Hasil secara keseluruhan berjumlah 3,041 dalam skala 4 dan dalam jumlah persentase memperoleh angka $76 \%$. Oleh karena itu, hasil evaluasi Pelaksanaan Penilaian Autentik Tahap Hasil ini dapat dikategorikan Baik. Artinya variasi desain pembelajaran dan penilaian membuat siswa senang mengikuti pelajaran. (Mardiani \& Sylvia, 2019).

\section{Kesimpulan}

Secara keseluruhan hasil dan pembahasan penelitian tentang Pelaksanaan Penilaian Autentik dalam Pembelajaran Sosiologi Kelas X Semester Ganjil (Januari-Juni) Tahun Ajaran 2020/2021 di SMA Negeri 1 Lubuk Basung, diperoleh kesimpulan bahwasannya pelaksanaan penilaian autentik dalam pembelajaran sosiologi di SMA Negeri 1 Lubuk Basung sudah terlaksana dengan Baik, dengan Perolehan Rerata sebesar 3,0239, Persentase 77\% yang berarti pelaksanaan penilaian autentik yang dilaksanakan oleh guru sosiologi di SMA Negeri 1 Lubuk Basung termasuk dalam Kategori Baik.

\section{Daftar Pustaka}

Alwidora, D., \& Wirdanengsih, W. (2020). Penerapan Sekolah Berintegrasi Budaya Minangkabau di SMA Negeri 5 Padang. Jurnal Sikola: Jurnal Kajian Pendidikan dan Pembelajaran, 2(1), 1-7. 2(1), 1-7.

Pertiwi, P., Marzuki, M., \& Sabri, T. Penilaian Autentik dalam Pembelajaran Tematik di Sekolah Dasar Negeri Kecamatan Sungai Ambawang. Jurnal Pendidikan dan Pembelajaran Khatulistiwa, 7(6), 1-10

Arif Amiruddin Jabbar, M. (2014). Analisis Visual Kriya Kayu Lame Di Kampung Saradan Desa Sukamulya Kecamatan Pagaden Kabupaten Subang. Disertasi. Universitas Pendidikan Indonesia.

Ati, A., Ruhimat, M., \& Yani, A. (2019). Pemahaman Guru Geografi Terhadap Konsep Dan Pelaksanaan Penilaian Autentik di SMA Negeri Pulau Buton. Edusentris, 6(2), 59-68.

Bendriyanti, R. P., \& Dewi, C. (2014). Model "Countanance Stake" Dalam Evaluasi Pembelajaran Bahasa Inggris Di Perguruan Tinggi. Seminar Nasional Riset Inovatif.

Nurdin, N, \& Hartati, S. (2019). Metodologi Penelitian Sosial. Jakarta: Kencana

Putri, Y.E, \& Fernandes, R. (2019). Pelaksanaan Integrasi Pendidikan Karakter Nilai Al-Qur'an dan Nilai Budaya Alam Minangkabau Dalam Pembelajaran Sosiologi (Studi Kasus: SMA Negeri 2 Padang dan SMA Adabiah Padang). Jurnal Sikola: Jurnal Kajian Pendidikan dan

Jurnal Sikola: Jurnal Kajian Pendidikan dan Pembelajaran Vol. 2, No. 2, Th. 2020 
Pembelajaran, 1(1), 1-6. https://doi.org/10.24036/sikola.v1i1.8

Gahara, B. (2017). Implementasi Penilaian Autentik Pada Pembelajaran Pendidikan Agama Islam Kurikulum 2013. Tanzhim, 1(01), 93-109.

Hadikusuma, Z. (2016). Pengembangan Penilaian Autentik Berbasis Kurikulum 2013 di Kelas IV Sekolah Dasar Negeri Kota Pekanbaru. Jurnal Tematik, 5(1), 1-10

Indriana, D. (2018). Evaluasi Pembelajaran dan Penilaian Autentik dalam Pembelajaran Bahasa Arab. al-Ittijah: Jurnal Keilmuan dan Kependidikan Bahasa Arab, 10(2), 34. https://doi.org/10.32678/al-ittijah.v10i02.1245

Laelasari, L. (2017). Penilaian Autentik Dalam Pembelajaran. Jurnal LP3M Sosiohumaniora, 3(2), $125-139$.

Mardiani, M., \& Sylvia, I. (2019). Pengembangan Tes Diagnostik Pilihan Objektif Tiga Tingkat Guna Mendeteksi Miskonsepsi Ciri-Ciri Sosiologi. Jurnal Sikola: Jurnal Kajian Pendidikan dan Pembelajaran, 1(1), 69-79. https://doi.org/10.24036/sikola.v1i1.1

Nahrowi, M. (2019). Pengembangan Model Penilaian Autentik dalam Pembelajaran Tematik Berbasis Higher Order Thinking Skill (HOTS) pada Madrasah Ibtidaiyah di Kecamatan Gebog Kabupaten Kudus. Elementary: Islamic Teacher Journal, 7(2), 279. https://doi.org/10.21043/elementary.v7i2.6005

Permatasari, R. T. (2013). Pengembangan instrumen penilaian autentik untuk mengukur keterampilan proses sains siswa kelas XI pada materi hidrokarbon Universitas Pendidikan Indonesia. Disertasi. Universitas Pendidikan Indonesia

Puspitasari, E. D. (2016). Keterlaksanaan Penilaian Autentik dan Korelasinya dengan Hasil Belajar Biologi SMA. Proceeding Biology Education Conference, 13(1), 196-202.

Rizkiwati, B. Y., \& Farid, L. F. (2018). Pengembangan Model Asesmen Autentik Berbasis Karakter Santri Sebagai Upaya Penyiapan Generasi Unggul dan Berdaya Saing. JPEK Jurnal Pendidikan Ekonomi dan Kewirausahaan, 1(2), 91. https://doi.org/10.29408/jpek.v1i2.556

Ramadhan, M. A., Iriani, T., \& Handoyo, S. S. (2013). Relevansi Kompetensi Lulusan SMK Khususnya Kompetensi Keahlian Teknik Gambar Bangunan Dengan Kompetensi Yang Dibutuhkan di Dunia Kerja. Jurnal Pensil: Pendidikan Teknik Sipil, 2(1), 1-10.

Suprananto, S. (2012). Penilaian (Assessment) dalam Pembelajaran. Penilaian Pendidikan, 13-14.

Sutama, S., Sandy, G. A., \& Fuadi, D. (2017). Pengelolaan Penilaian Autentik Kurikulum 2013 Mata Pelajaran Matematika di SMA. Manajemen Pendidikan, 12(1), 105. https://doi.org/10.23917/jmp.v12i1.2967

Sylvia, I., Anwar, S., \& Khairani, K. (2019). Pengembangan Instrumen Penilaian Autentik Berbasis Pendekatan Authentic Inquiry Learning Pada Mata Pelajaran Sosiologi di Sekolah Menengah Atas. Socius, 6(2), 103-120. https://doi.org/10.24036/scs.v6i2.162 